\title{
THE STUDY OF BRITISH CULTURE EXPRESSED BY THE WRITERS OF 1950S
}

\author{
Dr. Rashmi Rani \\ Assistant Professor, Lokmanya Tilak College of Engineering \\ Sector-4, Vikas Nagar, Koparkhairane- 400709, Navi Mumbai \\ Maharashtra, India
}

\begin{abstract}
The researcher aims to study the British culture expressed by the writers of 50s.The modern novel particularly 1950s emphasizes the problems of the modern culture. Eliot and Auden rightly called this age the age of lost generation. Like these two poets, the novelists also depict the decay of human relations and values in the novels. Man is presented as confused since the road of his life is not straight. Man has lost the personal touch and thus has become neutral to the problems of other. The modern man is also suffering psychologically which is depicted by Bennett, John Galsworthy, and so on. The emergence of many theories also confused the man, these theories made him indecisive. The political scenario, for instance, two World Wars uprooted the man from his roots which is responsible for being insensitive. All the modern novelists responded in a different way to these problems in their works. But at the core of their writing is always the culture particularly the changed one which brought the problems to the modern man.
\end{abstract}

Keywords - culture, acculturation, intellectual, leisure

\section{INTRODUCTION}

Every human society has its own particular culture, or socio-cultural system, which overlaps to some extent with other systems. Variation among socio-cultural systems is attributable to physical habitats and resources, to the range of possibilities inherent in various areas of activity, such as rituals, language and customs.

In his essay "Culture and Anarchy" Matthew Arnold defines culture with its motive in a very prominent manner. According to him; there is a view in which all the love of our neighbor, the impulses towards action, help and beneficence, the desire for removing human error, is to make a perfect and better world:

Culture is then properly described not as having its origin in curiosity, but as having its origin in the love of perfection; it is a study of perfection. ${ }^{1}$

Arnold sees culture as a mean through which human race can reach to its deal:
It is in making endless additions to itself, in the endless expansion of its powers, in endless growth in wisdom and beauty, that in spirit of the human race finds its deal. To reach this ideal, culture is an Indispensable aid and that is true value of culture. ${ }^{2}$

The transition to democracy is unlikely to occur without disaster; if English people persist in their belief that in all circumstances, 'it is a happiest and important thing for a man merely to be able to do as he likes.' If their individualism is not to sweep them into anarchy, English people must modify their attitude towards public authority.

They must acquire the notion, so familiar on the continent and to antiquity of the state. In the process of acculturation, an individual learns the forms of conduct acceptable to his group. He does this so well that his thoughts, his values and his acts rarely conflict with those of other members of his society.

Culture is a man- made environment and the function of this external, man- made environment is to make life secure and enduring for the society of human beings living within the cultural system. In this regard D. H. Lawrence has criticized the modern world:

Our civilization... has almost destroyed the natural flow of common sympathy between men and men, men and women. And it is this that $I$ want to restore into life.3

Britain has experienced a period of accelerated social and cultural change in 1950s. This has coincided with the disintegration of British Empire, an expansion of the Commonwealth and the immigration of people of numerous nationalities, languages and cultures. The gradual globalizing of life to which these phenomena have contributed, has produced a multi-ethnic Britain, with a popularity of identities and heritages. The most important cultural and intellectual phenomenon of the years after 1945 was the upheaval and extensive abandonment of traditional values, and the quest for new values felt to be more appropriate to life in a rapidly 
changing, materialistic and scientific civilization. This could be described in various ways. The novelist, C. P. Snow, described it as gulf between 'the two cultures', scientific and literary.

One of the most important cultural changes during this period was the women's movement. In the traditional Britain society women were supposed to be at home only. No woman and no man tried to think against this notion. But the first step towards the cultural and social change was taken during the Second World War (1939-45), many women had gone to work in the fields and factories. There after they were encouraged to return to their domestic roles as wives and mothers and at the same time there were indications of domestic unhappiness. As a result, more and more women began seeking the services of psychiatrists and marriage guidance counselors. Worries about women's independence intensified following the publication of an American study called Sexual Behavior in Human Female, better known as the Second Kinsey Report et al. (1953). It revealed that women could enjoy sex as much as men, and that discontent and adultery in marriage were even common. The findings caused the beginning of another important cultural change in the form sexual openness in Britain. Sexual ethics, especially, underwent a rapid and drastic change, just as views on what constituted 'public decency' changed as regards literature, stage and television. David Christopher very prominently describes:

\section{But within three years of Kinsey report, the limits of censorship in the arts and entertainments became more relaxed and many films, plays and books began to include sexually explicit material.4}

Homosexuality came to be more openly discussed and more commonly regarded as an affliction than a vice.

A drastic change also appeared in the life- style of society. Liberty and the pursuit of happiness was the main concern of $1950 \mathrm{~s}$ Britain. Society was younger, richer and more image conscious. With full employment, it was easy to achieve financial independence at an early age. Business began to market their products to teenagers who now had enough money to create a new world of their own. Fashionable clothes, hair styles and records were among the most popular items. Coffee and melody bars opened, providing meeting places for a generation with money to spend on leisure and pleasure. The middle classes, followed closely by the newly well- to- do working classes. They spent more of their money on cars, television, washing machines, refrigerators, and a wide range of other electrical gadgets. The increase in the spending power of young people, together with the unexpected surge in the post- war birth rate, had produced a much bigger and more noticeable gulf between the young and old. As Mr. Mark Abrams reflected, in an important survey of changing habits:

\section{It is hardly surprising that the sense of alienation between the generations should seem more than normal in contemporary Britain.5}

Cultural material was increasingly created for mass audiences in the form of television programs, popular music and films. But some social commentators and academics were concerned about the mass consumption of films and music which had been created simply to make profits. They believed that standards and quality in the arts would fail. Like many earlier critics such as Matthew Arnold and T. S. Eliot, F. R. Leavis believed that great works of arts carried a moral, civilizing message, which was educational, and a means of social and self- improvement.

Moreover, in terms of crime also there appeared a disconcerting fact. Before war; the crime was largely caused by slums, poverty and bad economic conditions. But in the 1950 s it was precisely among teenagers, whose income had risen most spectacularly, that there appeared gang warfare, vice and the propensity to commit violent crime. A government report in 1959 remarked:

\section{It is disquieting feature of our society that, in the years since the war, rising standards in material prosperity, education and social welfare have brought no decrease in the high rate of crime reached during the war: on the contrary, crime has increased and is still increasing. 6}

The conclusion seemed to be that crime is determined not by material conditions alone, but by the whole social environment including such intangible factors as the ethical standards and the values prevalent in society that 'a community gets the criminals it deserves' was truer, perhaps, than the original makers of the phrase had known.

Several influential books were written expressing the probable consequences due to drastic cultural changes. In The Uses of Literacy et al. (1957) Richard Hoggart studied the consequences for the individual. He believed that the absence of moral content in popular literature and the arts had made it more difficult for the ordinary person to become educated, wise and cultured. In the book The Long Revolution et al (1961) Raymond Williams considered the social consequences. He thought it would lead to an increase in material, self- interest, a reduction in the importance of the social services (such as education and health) and a less radical, more individualistic Labor Party. But he also believed 
that the negative effects could be combated with a strong leftwing government and better standards of education.

The 1950s society of Britain is described in many of Kingsley Amis' novels. His novels are not only engrossing but also set the reader thinking about conflicting situations men have to face. This is so because, instead of narrating a story of their actions, Amis highlighted the hidden face of their actions. Bernard Bergonzi rightly describes his fiction:

His fiction is marked by an acute comic sense, a finely responsive eye and ear for social nuance, concern about the difficulties of behaving decently and an intermittent sense of nightmare. 7

His first novel, Lucky Jim (1954) was highly appreciated as light comedy of high order. Amis' attitude towards the social adjustment; he endorses has altered in the course of his fictional career. His second novel, That Uncertain Feeling, least certain, least consoling novel, and one that seems to catch contemporary social references strikingly, even develops sympathy for the man who is unable to adjust and must retreat to the provincial society; he came from. The class difference gives the story another dimension and links it with other examples of literature of protest of the 1950s e.g. Osborne's Look Back in Anger.

Later in Take a Girl Like You (1960) due to social and cultural changes, questions about the value of adjustment become more a matter of superficial comedy and the worth of adjustment, like that of learning to order a meal, drive a car, or lose virginity, is taken for granted. Take a Girl Like You explores almost all the variants of sexual persuasion and pursuit and is a most accurate and devastating comedy of contemporary sexual mores and manners. Malcolm Bradbury has rightly said:

\section{It opened the way for Amis to take on a new kind of writing in which the $1960 \mathrm{~s} \operatorname{mood}$ of sexual liberation and then of growing male- female conflict were to be dominant themes.8}

\section{CONCLUSION}

Kingsley's contempt for experimentation in the novel and for all modernist ideas led him to return to traditional forms, and also though rather more reluctantly, to the embracing arms of no less than three literary movements. First there was the provincial movement, a group headed by William Copper. Second, there was the movement itself. And finally there was 'Angry Young Men', a rebellion he supposedly led. Amis has never been or claimed to an iconoclast about society. Rather, the novels, whatever the setting, demonstrate an acceptance, no matter how ironic or grudging, of the social status quo.

Committed social rebels, those who would transform society in terms of a new or resurrected vision, are either peripheral fools or non-existent in Amis' fiction.9

\section{REFERENCE}

[1] R.H. Super, ed. (1965). Matthew Arnold, USA: The University of Michigan press, (pp. 91).

[2] R.H. Super, ed. (1965). Matthew Arnold, USA: The University of Michigan press, (pp. 94).

[3] Williams Raymond. (1965). Culture and Society, London: Chatto \& Windus, (pp. 215).

[4] Christopher David. (1999). British Culture: An Introduction, London: Routledge, (pp. 4).

[5] Cantor F. and Werthman Michael S. (1968). The History of Popular Culture Since 1815, USA: The Macmillan Company, (pp. 49).

[6] Thomson David. (1864). England in the Twentieth Century (1914-63), London: Jonathan Cape, (PP. 227).

[7] Bergonzi Bernard. (1979). The Situation of Novel, London: macmillan, (pp. 16).

[8] Stade George ed. (2005). The Encyclopedia of British Writers: 20th Century, New Delhi: Viva Books Pvt. Ltd. (pp. 8).

[9] Henderson Lesley. (1991). Contemporary Novelist, London: St. James Press, (pp. 34). 